\title{
ZMIANY DYREKTYWY O AUDIOWIZUALNYCH USEUGACH MEDIALNYCH W ŚWIETLE POLITYKI UNII EUROPEJSKIEJ
}

\section{Abstract \\ REVISION OF THE AUDIOVISUAL MEDIA SERVICES DIRECTIVE IN THE LIGHT OF EUROPEAN MEDIA POLICY}

The Audiovisual Media Services Directive, 2010/13/UE, due to development of convergence and digitalization phenomena, has responded to the technological paradigm shift, thereby continuing the late 1980s standard of transfrontier television. The dramatic shift of all aspects of audiovisual sector which has occurred for the last decade, triggered the adoption of its revision on the $14^{\text {th }}$ of November, 2018 which creates a media framework for the $21^{\text {st }}$ century. The aim of the article is to point out - within the frame of historical aspects of European media policy, including a digital single market impact - the wide spectrum of its implications, taking into consideration the dual - cultural and economic - status of audiovisual media services. Hence, the analysis of certain regulatory changes, concerning the following issues, ought to be mentioned: 1) the scope of the audiovisual media notion; 2) principles of jurisdiction; 3) independence of national media regulators; 4) promotion of European works; 5) requirements for audiovisual commercial communications; 6) consumer protection. The presentation of the subject in the light of the regulation historical aspects allows to come to the certain conclusions regarding the political, economic, social and cultural feasible results of the mentioned changes and their impact on media organisation and management in the new audiovisual environment. Therefore, the legal approach is justified; the interpretation of the law with the subsidiary role of methodological trend of legal hermeneutics are applied.

The undertaken subject is up-to-date. Moreover, it is needed to be notified as the Member States are obliged to implement the directive by the $19^{\text {th }}$ of September, 2020 .

Keywords: audiovisual media services, law, European Union 


\section{Wprowadzenie}

U podłoża dyrektywy Parlamentu Europejskiego i Rady (UE) 2018/1808 z dnia 14 listopada 2018 r. zmieniającej dyrektywę 2010/13/UE w sprawie koordynacji niektórych przepisów ustawowych, wykonawczych i administracyjnych państw członkowskich dotyczących świadczenia audiowizualnych usług medialnych (dyrektywa o audiowizualnych usługach medialnych) ze względu na zmianę sytuacji na rynku (dyrektywa o audiowizualnych usługach medialnych, dalej: DAUM) (Dz. Urz. UE L 303/69) leżą dynamicznie zachodzące w ostatniej dekadzie, determinowane rozwojem technologii informacyjno-komunikacyjnych (TIK), zmiany sektora audiowizualnego. Postrzegany jest on dualnie - w perspektywie zarówno europejskiego jednolitego rynku cyfrowego (COM(2015) 192 final, pkt 2), jak i nośnika informacji, edukacji i rozrywki, ergo kluczowego segmentu zachowania i wzmocnienia różnorodności kulturowej na kontynencie. Rozwiązania zawarte w DAUM oparte są na technologiczno-przemysłowej i kulturowo-społecznej konwergencji (Jenkins, 2006, s. 2-3): zawartości i technologii jej przekazu, podmiotów, zaangażowanych w proces jej tworzenia i odbioru, oraz biznesowej, rozpatrywanej z punktu widzenia zintegrowanych modeli zarządzania (Badźmirowska-Masłowska, 2008, s. 16; Kowalski, 2014, s. 15-36) ${ }^{1}$. Europeizacja w obszarze mediów audiowizualnych zachodzi w dziedzinach: politycznej, kulturowej i rynkowej (Jakubowicz, 2010, s. 242-256); jej pogłębianie uwidacznia się szczególnie w implikacjach polityki publicznej, dotyczącej zacierania się granic pomiędzy regulacjami, odnoszącymi się do treści, telekomunikacji i łańcucha dystrybucyjnego, ergo przejścia $\mathrm{z}$ modelu pionowego do skonsolidowanego wzorca poziomego (Chałubińska-Jentkiewicz, 2011, s. 55-67; Nowak, 2014, s. 29-60)². Zagadnienia te wpisują się zarówno w szeroki nurt mediów jako zjawiska polityczno-gospodarczego i społecznego, jak i w systemowe ujęcie zarządzania organizacjami medialnymi. Słusznie podnosi się, że w warunkach rozwoju technologicznego wyzwaniem stają się nieustanne zmiany i wysoki poziom niepewności otoczenia, w jakim funkcjonują (Nierenberg, 2013, s. 41-47); istotnym elementem jest tu środowisko prawne, co skłania do przyjęcia przy badaniu niniejszych zagadnień podejścia właściwego tej dyscyplinie, $\mathrm{z}$ wiodącą rolą metody analizy interpretacyjnej tekstu prawnego, uzupełnianej elementami nurtu metodologicznego hermeneutyki prawniczej.

1 Henry Jenkins dzieli konwergencję na: 1) technologiczną - dotyczącą między innymi „skonwergowania” treści medialnych, dostarczanych w ramach dywergentnych platform; 2) ekonomiczną - związaną m.in. z integracją i horyzontalną, i wertykalną rynków telekomunikacji, technologii informacyjnych i mediów, czy szerzej przemysłu rozrywkowego; 3) społeczną i kulturową - obejmującą funkcjonowanie w odnośnym środowisku technicznym i rynkowym oraz 4) globalną, w zakresie obrotu zawartością (Jenkins, 2001).

2 Uproszczony model obejmuje obecnie: producenta zawartości i jej wydawcę (publisher), udostępniającego (content host and platforms), dostawcę usług internetowych (Internet service providers) oraz wyszukiwanie, nawigację, urządzenia konsumenckie (European Regulators Group for Audiovisual Media Services, 2015, s. 5, 20-27, 48-59). 
Zmiany dyrektywy 2018/1808/UE dotyczą następujących, przedmiotowo wyszczególnionych kwestii: 1) poszerzenia zakresu pojęcia mediów audiowizualnych o platformy udostępniania wideo; 2) uproszczenia kryteriów jurysdykcyjnych; 3) zwiększenia roli ciał regulujących i ich uniezależnienia zarówno od władz publicznych, jak i podmiotów rynkowych; 4) promocji treści europejskich; 5) handlowych przekazów audiowizualnych; 6) zwiększenia ochrony konsumenta ${ }^{3}$. Ich przegląd poprzedzono uwagami dotyczącymi prawno-instytucjonalnego podłoża i historycznego kontekstu, charakteru i celów polityki medialnej Unii Europejskiej $(\mathrm{UE})^{4}$, uwzględniającej problematykę odmiennej roli i pozycji rynkowej prywatnych i publicznych podmiotów wyrażających w swej misji interes publiczny w ujęciu narodowym, ale podlegających też unijnej presji komercyjnej (Chałubińska-Jentkiewicz, 2011, s. 68-154).

Podejmowana problematyka jest istotna, zwłaszcza że państwa członkowskie Unii Europejskiej zobowiązane są do implementacji postanowień tytułowej dyrektywy do dnia 20 września 2020 roku. Przy ich sygnalizowaniu należy mieć jednak na uwadze, że syntetyczne ukazanie kierunku zmian regulacyjnych pozwala jedynie na predyktywny charakter wyprowadzanych wniosków i stanowi punkt wyjściowy do dalszych rozważań, obejmujących komparatystyczne aspekty oceny procesu harmonizacji dokonywanego indywidualnie, na szczeblu krajowym. Przyczynkiem do dyskusji mogą być - skierowane w ramach konsultacji do administracji publicznej i interesariuszy reprezentujących zwłaszcza podmioty rynkowe, organizacje pozarządowe czy środowiska naukowe - pytania przygotowane przez Krajową Radę Radiofonii i Telewizji (KRRiT) w uzgodnieniu z Ministrem Kultury i Dziedzictwa Narodowego i we współpracy z Ministrem Cyfryzacji.

\section{Europejska polityka medialna w świetle dyrektywy o „telewizji bez granic"}

Media masowe in corpore nie stanowiły i nadal nie stanowią wydzielonej kompetencji wspólnotowej, podlegając rozproszonym przepisom prawa pierwotnego (traktaty: https://europa.eu/european-union/law/treaties_en [11.04.2020]) i wtórnego ${ }^{5}$, dedykowanego politykom łączącym się zwłaszcza ze swobodami przepły-

3 W perspektywie zarządzania organizacją medialną na poziomie europejskim szczególnego znaczenia nabierają kwestie handlowych przekazów medialnych i wspierania twórczości europejskiej w jej aspektach: kulturowym, kreatywnym i gospodarczym, które wymagają odrębnego, pogłębionego opracowania.

4 Traktowanej jako kontynuacja polityki Europejskiej Wspólnoty Gospodarczej (EWG) i Wspólnoty Europejskiej (WE).

5 Któremu podlegały też aspekty rynkowe przemysłu filmowego. W załączniku III do art. 106 ust. 3 Traktatu Ustanawiającego Europejską Wspólnotę Gospodarczą, Lista transakcji niewidocznych, wymieniono wszelkie: reklamy, prasę, książki, publikacje muzyczne, nagrania, wraz z ich 
wów (towarów oraz usług, osób i kapitału), konkurencją i ochroną konsumenta, przemysłem, telekomunikacją czy kulturą (Mik, 1999, s. 44, 147-322, 323-560). Sektor audiowizualny traktowany jest jako główna dziedzina rynku wewnętrznego w segmencie przemysłów kultury strukturalnie w największym stopniu podlegająca wpływom technologicznym, jednocześnie o wysokim potencjale gospodarczym i oddziaływaniu społeczno-kulturowym w zakresie zachowania i rozwoju europejskiego dziedzictwa, zapewnienia pluralizmu, promowania społecznej inkluzywności i odpowiedzialności, w tym ochrony małoletniego i kreowania społeczeństwa informacyjnego (Jakubowicz, 2010, s. 33 i n.).

Rozpatrując zatem implikacje nowelizacji DAUM, nie sposób abstrahować od kontekstu wpisującego ją w continuum polityki Unii Europejskiej (UE) i Rady Europy (RE), przyjętej koherentnie przez obydwie organizacje na początku lat dziewięćdziesiątych ubiegłego wieku i sukcesywnie stosowanej pierwotnie względem rozpowszechniania, a następnie względem transgranicznych usług medialnych „na żądanie”, przenosząc nacisk z tradycyjnych mediów masowych na indywidualne ich rodzaje (Tofler, 2002, s. 441-447; Krzysztofek, 2006, s. 1 i n.; Castells, 2014).

Można wyodrębnić, świadczące o ciągłości podejmowanych inicjatyw, następujące fazy transformacyjne:

1) utworzenie wspólnego standardu - uwidocznionego w europejskiej konwencji o telewizji ponadgranicznej, sporządzonej w Strasburgu dnia 5 maja 1989 r. (Dz.U. 1995 nr 32 poz. 160), i dyrektywie 89/552/EWG Parlamentu Europejskiego i Rady z dnia 3 października 1989 r. w sprawie koordynacji niektórych przepisów ustawowych, wykonawczych i administracyjnych państw członkowskich dotyczących świadczenia audiowizualnych usług medialnych (dyrektywa o audiowizualnych usługach medialnych) (Dz.Urz. UE L 298/23) - uwarunkowane upowszechnieniem technologii satelitarnej i kablowej, to jest transgranicznością przekazu (COM(84) 300 final), skutkujące zniesieniem monopoli państwowych i pojawieniem się dualnego - publiczno-prywatnego - systemu nadawczego;

2) rozwój mediów audiowizualnych - uwidoczniony głównie w rewizjach wymienionych aktów prawnych: protokół poprawek sporządzony w Strasburgu dnia 9 września 1998 r. do Europejskiej konwencji o telewizji ponadgranicznej, sporządzonej w Strasburgu dnia 5 maja 1989 r. (Dz.U. 2004 r., Nr 28, poz. 250) i dyrektywa 97/36/WE Parlamentu Europejskiego i Rady z dnia 30 czerwca 1997 r. zmieniająca dyrektywę Rady 89/552/EWG, w sprawie koordynacji niektórych przepisów ustawowych, wykonawczych i administracyjnych Państw Członkowskich dotyczących wykonywania telewizyjnej działalności transmisyjnej (Dz.Urz. UE L 202/60) - charakteryzujących się pojawianiem coraz szerszej sfragmentaryzowanej oferty programowej

prenumerowaniem, filmy ( $w$ tym opłaty związane $\mathrm{z}$ kinematografią, $\mathrm{z}$ tytułu subskrypcji, powielania, synchronizacji), prawa autorskie etc. (Nikoltchev, European Audiovisual Observatory, 2006). 
obejmującej też trudne do klasyfikacji usługi typu pay-per-view (PPV), video-on-demand („wideo na życzenie/żądanie” - VoD) ${ }^{6}$ i kanałów ich udostępniania oraz

3) wprowadzanie sukcesywnie w niniejszy obszar regulacyjny nowych rodzajów usług: „na żądanie”, a następnie „platform udostępniania wideo” (dyrektywa Parlamentu Europejskiego i Rady 2010/13/UE z dnia 10.03.2010 r. w sprawie koordynacji niektórych przepisów ustawowych, wykonawczych i administracyjnych państw członkowskich dotyczących świadczenia audiowizualnych usług medialnych; dyrektywa o audiowizualnych usługach medialnych, Dz.Urz. UE L 95/1; i właśnie jej obecna rewizja - 2018/1808/UE Dz.Urz. UE L 303) - z paralelnym przekształcaniem się biernego paradygmatu odbiorczego w aktywny, prowadzący do wzorca użytkownika i twórcy.

Upowszechnienie technologii satelitarnej i kablowej, ergo transgraniczności przekazu doprowadziło w latach osiemdziesiątych ubiegłego wieku do ukształtowania się podstaw europejskiej polityki stricte łączącej się z programowymi aspektami rozpowszechniania telewizyjnego, osłabiając tym samym trwający niemal przez półwiecze państwowy monopol regulacyjny, ale też dominację publicznego sektora - przez wprowadzenie do gry rynkowej szerokiego spektrum komercyjnych podmiotów prywatnych (Dobek-Ostrowska, 2007; Hallin, Mancini, 2007; Jakubowicz, 2010, s. 27-44; Chałubińska-Jentkiewicz, 2011, s. 66-85) 7 . Ponadto powstały - niezakończone sukcesem, a ukierunkowane na tworzenie wspólnej przestrzeni kulturowej - inicjatywy powołania „paneuropejskich” telewizji Eurikon i Europa.

Przyjęcie dyrektywy o „telewizji bez granic” (89/552/EWG) uwidoczniło wiodącą rolę motywowanego gospodarczo paradygmatu liberalno-deregulacyjnego umożliwiającego krajom Europejskiej Wspólnoty Gospodarczej (EWG) wspólne konkurowanie w skali globalnej oparte na mechanizmach wolnorynkowych (Jakubowicz, 2010, s. 27-44). Minimalna harmonizacja przepisów ustawowych, wykonawczych i administracyjnych, służyła usuwaniu rozbieżności regulacyjnych, potencjalnie zakłócających swobodny przepływ programów, między państwami członkowskimi także w zakresie wymiany handlowej oraz prawa konkurencji i ochrony konsumenta ${ }^{8}$. Celem zażegnania konfliktów jurysdykcyjnych za kryterium wiodące przyjęto państwo ich pochodzenia, a wtórne miały charakter

6 Związanego pierwotnie z etapem rozwoju magnetowidów i kaset wideo, następnie z cyfryzacją sygnału, rozwojem szerokopasmowego Internetu i kolejnych generacji telefonii komórkowej (Lange et al., 2009, s. 14). Por. też: Mediakabel BV vs Commissariaat voor de Media (C-89/04), rozpatrywana w trybie prejudycjalnym, przez Trybunał Sprawiedliwości (TS). Wyrok Trybunału (trzecia izba) $\mathrm{z}$ dnia 2 czerwca $2005 \mathrm{r}$.

7 Dla polskiego modelu regulacyjnego szczególne znaczenie ma system francuski (Romanowski, 1999, s. 35-55).

8 Por. w tym kontekście orientacje dotyczące ingerencji państwa w media (Nierenberg, 2013, s. $45-46)$. 
techniczny ${ }^{9}$. Nadawanie uznano za - odzwierciedlającą wolność wyrażania opinii $\mathrm{w}$ ich pluralistycznym wachlarzu - usługę $\mathrm{w}$ rozumieniu traktatowym, ergo zasadzie swobody podlegało zarówno rozpowszechnianie, jak i rozprowadzanie programów, bez potrzeby ich wtórnej kontroli w państwach odbioru, co - skądinąd - wyrażało integracyjny aspekt polityki EWG w tym zakresie. Sprzyjało to uwspólnotowieniu rynków produkcji i dystrybucji na zasadach uczciwej konkurencji, ułatwiając publicznym i zwłaszcza prywatnym podmiotom rozpoczynanie i prowadzenie działalności. Metodę koordynacyjną ${ }^{10}$ ukierunkowano na: 1) zachowanie dziedzictwa europejskiego i wzmocnienie różnorodności kulturowej przez wprowadzenie tak zwanych kwot europejskich, to jest przeznaczania większościowego czasu antenowego na twórczość europejską, a 10\% budżetu lub czasu nadawania na programy producentów niezależnych, $\mathrm{z}$ uwzględnieniem ich aktualnego wolumenu; 2) ochronę interesów konsumentów gwarantowanych: a) minimalnymi zasadami dotyczącymi reklamy telewizyjnej, obejmującymi zwłaszcza zakazy przedmiotowe co do wyrobów tytoniowych, produktów i zabiegów leczniczych dostępnych jedynie na receptę i ograniczenia w przypadku wyrobów alkoholowych; b) prawem do odpowiedzi w przypadku naruszenia dóbr osobistych nieprawdziwą informacją; c) ochronę małoletniego przed programami zagrażającymi lub mogącymi zagrażać jego fizycznemu, psychicznemu lub moralnemu rozwojowi (Badźmirowska-Masłowska, 2013, s. 213-260).

Postępująca w latach dziewięćdziesiątych globalizacja, w ramach której dominującą rolę zaczął odgrywać przemysł audiowizualny Stanów Zjednoczonych Ameryki Północnej, a na znaczeniu zyskiwały produkcje azjatyckie i południowo-amerykańskie, spowodowała, że akcent przesunął się na relacje negocjacyjne z innymi organizacjami międzynarodowymi, zwłaszcza ze Światową Organizacją Handlu $(\mathrm{WTO})^{11}$. Unia Europejska, kontynuując politykę medialną EWG, ponowiła sta-

9 To jest wykorzystanie częstotliwości lub pojemności satelitarnej przyznanej przez dane państwo członkowskie lub stację dosyłową do satelity, zlokalizowaną na jego terytorium.

10 Zgodnie $\mathrm{z}$ metodą harmonizacji minimalnej pominięto aspekty organizacyjne, to jest system koncesjonowania, zezwoleń administracyjnych, finansowania, form prawnych prowadzenia działalności medialnej oraz zgodnej z prawem treści programowej, które pozostały w kompetencji krajowej (Klafkowska-Waśniowska, 2016, s. 54-56).

11 Notabene problematyka zobowiązań podjętych przez Polskę w ramach Układu Ogólnego w sprawie Handlu Usługami (GATS) stanowiła istotny element negocjacji z UE w obszarze Kultura i polityka audiowizualna. Porozumienie ustanawiajace Światowa Organizację Handlu (WTO), sporządzone w Marrakeszu dnia 15 kwietnia 1994 r. oraz przystąpienie Polski do omawianej organizacji (Dz.U.95.98.483) niosły ze sobą określone konsekwencje prawne (Polska - odstępstwa od artykułu II: Zasada największego uprzywilejowania oraz Polska - Lista szczegółowych zobowiązań) w zakresie zobowiązań horyzontalnych. Dotyczyło to zwłaszcza: najważniejszego zobowiązania ogólnego członka WTO, to jest klauzuli największego uprzywilejowania (art. II) oraz zasady traktowania narodowego, w ramach których odstępstwem były preferencyjne zasady traktowania europejskiej twórczości audiowizualnej (kwoty większościowe).

Polska w rundzie urugwajskiej dążyła do wypracowania wspólnej z państwami członkowskimi WE polityki wyłączenia lub znacznego ograniczenia sfery audiowizualnej jako zróżnicowanej 
wiane u jej pierwocin pytanie o zdolność rywalizacji na rynku światowym w zakresie gospodarczym (w tym odnoszącym się do tworzenia miejsc pracy); pojawiło się też nowe wyzwanie, łączące się z kulturowym jej wpływem na powstające społeczeństwo informacyjne (Kasperkiewicz, 2004, s. 309-319; Jakubowicz, 2010, s. 55-65).

Wprowadzane dyrektywą 97/36/WE zmiany - znajdujące oparcie w art. 128 ust. 2 Traktatu ustanawiającego Wspólnotę Europejską - miały na celu przede wszystkim wzmocnienie ekonomiczne i podnoszenie konkurencyjności europejskiego sektora audiowizualnego, w tym przez wspieranie produkowania filmów fabularnych skierowanych do publiczności międzynarodowej. Postanowienia dotyczyły zapewnienia wolności gospodarczej podmiotom komercyjnym, ograniczanej jedynie wymogami ochrony widzów i powinnościami wynikającymi z kulturowego charakteru świadczonych usług. W dualnym systemie, niezależnemu od wpływów władz i podmiotów rynkowych, segmentowi publicznej telewizji, integralnie związanemu z potrzebami demokratycznymi i społecznymi właściwymi danym krajom, przypisano obowiązek pełnienia misji w zakresie dostarczania i szerokiego udostępniania spluralizowanej informacji i szerokiej oferty edukacyjnej, kulturalnej czy sportowej, dedykowanej zarówno całemu społeczeństwu jako całości, jak i jego częściom (Jakubowicz, 2010, s. 78-92; Dz.Urz. UE C 257/01; Dz.Urz. UE C 326/312).

Szczególne znaczenie należy przypisać nowemu ukształtowaniu zasad jurysdykcji, ukierunkowanych na ustalenie rzeczywistego miejsca prowadzonej przez czas nieokreślony działalności gospodarczej przez przedsiębiorstwo - ergo objęcie swym zakresem możliwie najszerszego kręgu stanów faktycznych i klarowne przyporządkowanie im określonej właściwości jurysdykcyjnej. Służyły temu normy o charakterze kolizyjnym, przewidujące określoną kolejność ich stosowania - począwszy od kryteriów związanych z miejscem siedziby, podejmowania decyzji w sprawie polityki programowej lub zatrudnienia znacznej części osób pracujących przy prowadzeniu działalności telewizyjnej, a na kryteriach technicznych skończywszy. Co istotne, regulacja zawartości została oddzielona od infrastrukturalnej, a media poddano zasadom neutralności technologicznej (Jakubowicz, 2010, s. 52-53; Van Eijk, 2011, s. 7-19).

kulturowej spuścizny i tożsamości kontynentu europejskiego, nie traktowanej stricte jako przedmiot handlu usługami. Finalnie „wyjątku kulturowego” nie uznano, jednakże UE nie wpisała sektora audiowizualnego na listę szczegółowych zobowiązań liberalizujących daną dziedzinę (Burri, 2013); ponadto podawano $\mathrm{w}$ wątpliwość zobowiązanie szczegółowe, to jest dostęp do rynku, w związku z ograniczeniami prawnych form działalności inwestorów zagranicznych i kapitału zagranicznego (ówcześnie na poziomie 33\%). Autorka brała udział w niniejszych negocjacjach. Zagadnienia te rozważano i nadal należy rozpatrywać w kontekście zobowiązań Światowej Organizacji Handlu (WTO) i Organizacji Współpracy Gospodarczej i Rozwoju (OECD) (Badźmirowska-Masłowska, Jędras, 2001, s. 4; Jakubowicz, 2010, s. 47-65; Cabrera Blázquez et al., 2016; European Audiovisual Observatory, Strasbourg, 2016, s. 37-39). 
Duże zmiany wiązały się z kwestiami konsumenckimi. Postanowienia dotyczące reklamy i sponsorowania rozciągnięto na nową formę przekazu - telesprzedaż, a ochronę małoletnich poszerzono o zakazujące zachęt do nienawiści ze względu na rasę, płeć, religię lub narodowość aspekty porządku publicznego, wzmacniając jednocześnie kontrolę ich egzekucji. Najważniejszą z nich był jednak obowiązek zapewnienia przez państwo członkowskie szerokiego dostępu odbiorców do bezpośrednich przekazów telewizyjnych lub ich retransmisji w ogólnodostępnej telewizji z wydarzeń o doniosłym znaczeniu dla społeczeństwa, to jest takich, które budzą zainteresowanie ogółu widowni. Jako przykład wymieniono te o charakterze sportowym (letnie i zimowe igrzyska olimpijskie i mistrzostwa świata w piłce nożnej) ${ }^{12}$; regulacje wykonywania $w$ tym zakresie praw wyłącznych miały zapobiegać obchodzeniu krajowych przepisów, chroniących uzasadniony interes ogólny.

\section{Dyrektywa o audiowizualnych usługach medialnych i skutki jej zmian}

Rozwój i upowszechnienie TIK znacząco wpłynęły na strukturę i organizację mediów audiowizualnych oraz sposoby prowadzenia przez nie działalności gospodarczej. W celu uzyskania optymalnych warunków konkurencyjności sektora audiowizualnego, za najistotniejszą zmianę dyrektywy 2010/13/UE uznano przedmiotowe poszerzenie jej zakresu definicyjnego o - wypełniające kryteria mediów masowych - audiowizualne usługi „na żądanie”13 (Klafkowska-Waśniowska, 2016, s. 94-98).

De lege lata, zatem, w pojęciu mediów audiowizualnych mieszczą się usługi w rozumieniu traktatowym obejmujące gospodarczą działalność świadczoną przez podmioty prywatne lub publiczne. Przybierają one formę: 1) linearną, umożliwiając równoczesny odbiór audycji na podstawie ich układu, przez włączenie się w tok programu (na przykład telewizja, transmisja strumieniowa na żywo, nadawanie w Internecie) lub 2) nielinearną, polegającą na wyborze czasu i konkretnej audycji „dysponowanej "na życzenie”" z katalogu swobodnie ukształtowanego co do treści i sposobu ich zestawienia oraz udostępnionego publicznie przez ich dostawcę, na przykład różne gatunki filmów, w tym seriale telewizyjne, transmisje wydarzeń sportowych lub kulturalnych, audycje przeznaczone dla dzieci (Apa, Gangemi, 2020, s. 98-103). Częścią składową audiowizualnych usług medialnych są też

12 Praktyczne wykorzystanie analogicznych, obowiązujących w Radzie Europy, rozwiązań miało miejsce w 2002 roku w związku z postulatem telewizji Polsat kodowania XVII Mistrzostw Świata w Piłce Nożnej. Autorka przygotowała wówczas na posiedzenie sejmowych Komisji Kultury i Środków Przekazu oraz Komisji Kultury Fizycznej i Sportu materiał pt. „Transmisje z Mistrzostw Świata 2002 roku w piłce nożnej” (Badźmirowska-Masłowska, 2002, s. 10 i n.).

13 Co ważne i wskazujące na kierunek rozwojowy sektora audiowizualnego, w trakcie prac nad dyrektywą 2010/13/UE proponowano, aby jej zakres regulacyjny obejmował wszystkie usługi audiowizualne. Ostatecznie jednak zawężono go do medialnych ich rodzajów. 
przekazy o charakterze handlowym (zwłaszcza: reklama, interaktywna i wirtualna, $\mathrm{w}$ tym split-screen, sponsorowanie, telesprzedaż, lokowanie produktu). Skłania to do wniosku o konieczności poddania ich obowiązkom o charakterze jakościowym (Klafkowska-Waśniowska, 2016, s. 297-356).

Głównym celem audiowizualnych usług medialnych jest dostarczanie ogółowi odbiorców audycji informacyjnych, edukacyjnych, rozrywkowych lub handlowych przekazów audiowizualnych, poprzez sieci łączności elektronicznej, a obowiązkiem dostawcy - ponoszącego odpowiedzialność redakcyjną - jest sprawowanie faktycznej nad nimi kontroli (której kryteria pozostawiono do ustalenia na szczeblu krajowym). W tym kontekście usługi „na żądanie” przybierają formę quasi-telewizyjną, skierowane są bowiem do tego samego, potencjalnie nieograniczonego, kręgu osób, które są odbiorcami przekazów telewizyjnych. Ze względu jednak na ich technologiczną i organizacyjną odmienność, wynikającą między innymi z wprowadzenia poza nadawcą pojęcia dostawcy usług medialnych oraz większego niż w przypadku rozpowszechniania poziomu kontroli ze strony użytkowników, zastosowano dwustopniowy system regulacyjny, obejmując je węższym zakresem wymogów, odnoszących się przede wszystkim do: identyfikacji dostawcy usługi, zakazu treści nacechowanych nienawiścią, a także odpowiednio do ochrony małoletniego i zasad dotyczących handlowych przekazów audiowizualnych. Co istotne z perspektywy praw konsumenta, nakazano zainicjowanie działań na rzecz dostępności mediów audiowizualnych dla osób z upośledzeniami wzroku lub słuchu.

Zjawiska cyfryzacji, konwergencji i globalizacji sprzyjają zwielokrotnieniu oferty usług medialnych i platform ich przekazu, tworząc nowe modele biznesowe dystrybucji treści podejmowane przez pojawiające się kategorie operatorów (na przykład multipleksu) oraz prowadząc do: fragmentaryzacji rynku i przekształcania się paradygmatu odbiorczego we wzorzec użytkownika i twórcy zawartości. Internet staje się też istotnym miejscem zatrudnienia i prowadzenia działalności przez przedsiębiorców ${ }^{14}$. Zmieniające się nawyki cechują zwłaszcza młode pokolenia, które są też pionierami innego korzystania $\mathrm{z}$ mediów audiowizualnych (na przykład przez rezygnację z tradycyjnych odbiorników na rzecz ich przenośnych rodzajów).

W ramach Strategii jednolitego rynku cyfrowego dla Europy (COM(2015) 192 final) podniesiono problem przeglądu dyrektywy 2010/13/UE w celu ukształtowania otoczenia regulacyjnego, kreującego ramy dla mediów w XXI wieku, ze szczególnym zwróceniem uwagi na zapewnienie równych warunków konkurencji

14 „Audiovisual media also increasingly target markets across national borders. At the end of 2013, more than 5,000 TV channels (not counting local channels and windows) were established in the EU. Of these, almost 2,000 targeted foreign markets (either EU or extra-EU). This share had increased from $28 \%$ in 2009 to $38 \%$ in 2013 As far as video-on-demand services are concerned, $31 \%$ of the video-on-demand services available in a Member State are established in another EU country", https://ec.europa.eu/commission/presscorner/detail/en/MEMO_16_1895 (dostęp: 12.05.2020); https://eur-lex.europa.eu/summary/chapter/audiovisual_and_media.html?root_default=SUM_1_ CODED\%3D05. 
tradycyjnej telewizji i nowo włączanych w niniejszy reżim usług („wideo na żądanie”, platformy udostępniania plików wideo czy treści audiowizualne w mediach społecznościowych) oraz wzmocnienie twórczości europejskiej i ochrony konsumenta. Znalazły one odzwierciedlenie w dyrektywie Parlamentu Europejskiego i Rady (UE) 2018/1808 z dnia 14 listopada 2018 r. zmieniającej dyrektywę 2010/13/ UE w sprawie koordynacji niektórych przepisów ustawowych, wykonawczych i administracyjnych państw członkowskich dotyczących świadczenia audiowizualnych usług medialnych (dyrektywa o audiowizualnych usługach medialnych) ze względu na zmianę sytuacji na rynku (Dz.Urz. UE L 303/69; European Commission, 2018a). Analizując ogólne założenia, należy wskazać następujące jej podstawy:

1) stworzenie równych warunków konkurencyjnych, niezależnie od rodzaju usługi i platformy, sposobu jej świadczenia (offline lub online), co stanowi potwierdzenie zasady neutralności technologicznej (Klafkowska-Waśniowska, 2016, s. 56-59);

2) wzmocnienie zasady państwa pochodzenia przy określaniu właściwości jurysdykcyjnych wraz z pozostawieniem możliwości elastycznego implementowania wymogów dyrektywy w sposób uwzględniający specyfikę państwa członkowskiego - umożliwiający zgodne z prawem unijnym wprowadzenie przepisów bardziej szczegółowych lub surowszych;

3) zwiększenie niezależności ciał regulujących w sektorze audiowizualnym i wzmocnienie współpracy między nimi przez powstanie Europejskiej Grupy Regulatorów ds. Audiowizualnych Usług Medialnych (ERGA);

4) zagwarantowanie wolności wypowiedzi oraz propagowanie różnorodności kulturowej w ramach promocji treści europejskich;

5) wzmocnienie ochrony konsumenta $w$ zakresie przeciwdziałania treściom nielegalnym oraz postanowień dotyczących handlowych przekazów audiowizualnych, w szczególności zaś ochrony małoletniego.

Wśród zmian dyrektywy 2018/1808/UE na uwagę zasługują przede wszystkim konsekwencje konwergencji usług telewizyjnych i internetowych $\mathrm{w}$ postaci pojawienia się nowych kategorii zawartości, to jest krótkich filmów wideo czy treści, pochodzących od użytkownika (KRRiT, 2018, s. 143-176). Z perspektywy rynkowej i społeczno-kulturowej fundamentalne jest włączenie w obręb dyrektywy - coraz bardziej dostępnych dla ogółu i mających silne oddziaływanie zwłaszcza na młodych odbiorców - usług platform udostępniania wideo ${ }^{15}$. Istotne jest tu jednak wypełnienie przez nie kryteriów usługi traktatowej ${ }^{16}$ o podstawowym celu lub zasadniczej funkcji ukierunkowanej na dostarczanie ogółowi odbiorców - przez sieci łączności elektronicznej - audycji lub wideo stworzonych przez użytkownika, o charakterze zwłaszcza rozrywkowym i edukacyjnym Dostawca platformy nie ponosi wprawdzie odpowiedzialności redakcyjnej, ale decyduje o sposobie

15 W ramach dodanego rozdziału IXA Przepisy majace zastosowanie do usług platform udostępniania wideo, art. 1 pkt 23, dot. art. 28a i 28b, w zw. z pkt 1b, dot. art. 1 ust 1aa).

16 Całości lub dającej się wyodrębnić jej części. 
ich zestawienia (również automatycznie lub za pomocą algorytmów). Oznacza to, że zmiany mogą dotknąć takie firmy, jak na przykład: Facebook, YouTube, Vimeo, Metacafe, Flickr, Netflix (KRRiT, 2018, s. 54-83). Mają one potencjalnie szeroki zakres. Dotyczą przede wszystkim ochrony konsumenta przed treściami niezgodnymi z prawem (C/2018/1177), nawołującymi do przemocy lub nienawiści, a także obowiązku sporządzenia przyjaznych dla użytkowników procedur i mechanizmów zgłaszania tego typu treści i reagowania na nie. Ponadto obejmują obowiązki informacyjne związane $\mathrm{z}$ handlowymi przekazami audiowizualnymi i zawierają przedmiotowe zakazy lub ograniczenia w zakresie reklamowania wyrobów tytoniowych i alkoholowych. Nacisk położono też na ochronę małoletniego przed audycjami, wideo stworzonymi przez użytkownika i handlowymi przekazami audiowizualnymi, mogącymi szkodzić jego rozwojowi. Dla realizacji wymienionych zadań postulowany jest szeroki wachlarz środków łączących rozwiązania prawne z - zyskującymi preponderancję - alternatywnymi ich rodzajami, jak na przykład: włączenie stosownych ograniczeń do regulaminu, zapewnienie systemów kontroli rodzicielskiej, oferowanie narzędzi do kształtowania umiejętności bezpiecznego i odpowiedzialnego korzystania z mediów - ukierunkowane są one na informację, profilaktykę i zwalczanie negatywnych skutków (Badźmirowska-Masłowska, 2017, s. 35-58). Zakres i charakter wymogów stawianych przed dostawcami platform udostępniania wideo mogą wpłynąć na aspekty strukturalne, model finansowania podmiotu, a w ogólności przekładać się na jego gospodarcze funkcjonowanie (KRRiT, 2018, s. 96-108).

W zakresie rozwiązań prawno-administracyjnych potwierdzono zasadę jurysdykcji terytorialnej, to jest kraju pochodzenia, a kryterium siedziby jest postrzegane integralnie w kontekście stałego miejsca podejmowania decyzji redakcyjnych i/lub zatrudnienia znacznej części pracowników zaangażowanych w prowadzenie działalności programowej. Uproszczono proceduralne aspekty współpracy między państwami członkowskimi i zobowiązano je do systemowego uzyskiwania informacji od dostawców usług o wszelkich przesłankach mogących wpływać na ustalenia w niniejszym zakresie. w szczególności obligatoryjne jest stworzenie rejestru dostawców platform udostępniania wideo mających siedzibę na terytorium danego kraju (Cole, 2018, s. 10-13). Państwa przyjmujące w ogólnym interesie publicznym (to jest stanowionym w ramach prawodawstwa Unii Europejskiej w obszarze przez nią koordynowanym) przepisy surowsze lub bardziej szczegółowe mogą przeciwdziałać zjawiskom delokalizacyjnym przez zastosowanie procedur, uwzględniających współpracę zarówno z państwem sprawującym jurysdykcję nad inkryminowanym dostawcą usług, jak i z Komisją Europejską (KE) i Komitetem Kontaktowym. Instytucjonalne aspekty wzmocniono przez położenie nacisku na zwiększenie niezależności krajowych ciał regulacyjnych od władz publicznych (rządów) i podmiotów rynkowych oraz wprowadzenie organu doradczego dla Komisji Europejskiej - stanowiącego forum wymiany informacji i doświadczeń Europejskiej Grupy Regulatorów ds. Audiowizualnych Usług Medialnych (ERGA), 
składającej się z reprezentantów krajowych, działających zwłaszcza na rzecz spójnego wdrożenia dyrektywy rewizyjnej.

Wzmocnieniu ulega też kulturowy komponent mediów audiowizualnych przez zobligowanie dostawców nielinearnych usług medialnych do zapewnienia co najmniej 30\% udziału utworów europejskich w swoich katalogach i ich stosowną ekspozycję. Państwa przyjmujące model wkładu finansowego w niniejszą produkcję mają możliwość zobowiązania do jego wnoszenia w wysokości proporcjonalnej i niedyskryminacyjnej, także dostawcę z siedzibą w innym państwie członkowskim, jeżeli kieruje on swoją ofertę na terytorium przyjmującego wskazywany model; jego wysokość ustala się na podstawie przychodów generowanych w państwach członkowskich, do których kierowana jest usługa. W mocy pozostają rozwiązania dotyczące większościowych, twórczych kwot europejskich i promowania poprzez przeznaczenie $10 \%$ czasu nadawania lub budżetu programowego dla europejskich producentów niezależnych (https://ec.europa.eu/digital-single-market/en/promotion-and-distribution-european-works; dostęp: 12.04.2020). Ponadto znaczenie zyskują programy: 1) zachowujące dziedzictwo filmowe (audiowizualne) (European Commission, 2018b) oraz 2) wspierające kulturę i sektor audiowizualny; w szczególności należy tu wskazać inicjatywę Komisji Europejskiej - Creative Europe (European Commission, 2018c), stanowiącą kontynuację programów Media (Kreatywna Europa, 2014-2020) i Kultura (https://ec.europa.eu/culture/our-programmes-and-actions/doc411_en).

Zmianie uległy też postanowienia dotyczące handlowych przekazów audiowizualnych (HPA); w szczególności: kryterium godziny zegarowej, limitujące czas nadawania spotów reklamowych i telesprzedażowych do $20 \%$, zastąpiono przedziałem godzin: 6.00-18.00 i 18.00-24.00. Dostawcy platform udostępniania wideo zostali zobowiązani do przestrzegania wymogów dla HPA, ustalonych dla audiowizualnych usług medialnych (łatwa ich rozpoznawalność), oraz zakazów: a) wykorzystywania technik podprogowych i ukrytych; b) naruszania godności człowieka, zawierania treści dyskryminujących; c) przedmiotowo odnoszących się do wyrobów tytoniowych, alkoholowych i leczniczych na preskrypcję; d) zachęcania do zachowań zagrażających życiu, zdrowiu, bezpieczeństwu, środowisku; ponadto HPA nie mogą wyrządzać fizycznej, psychicznej lub moralnej szkody małoletnim (poprzez na przykład nakłanianie do kupna lub najmu produktu wykorzystanie ich braku doświadczenia i łatwowierności). Dostawcy platform mają też obowiązek informowania o występowaniu HPA w audycjach i wideo stworzonych przez użytkownika. 


\section{Krajowa Rada Radiofonii i Telewizji. Konsultacje procesu implementacyjnego}

Jak już sygnalizowano, państwa członkowskie mają obowiązek implementować postanowienia dyrektywy 2018/1808/UE do dnia 19 września 2020 roku przez wprowadzenie w życie przepisów ustawowych, wykonawczych i administracyjnych, niezbędnych do jej realizacji. Dlatego Krajowa Rada Radiofonii i Telewizji między 30 października a 7 grudnia 2019 roku przeprowadziła w tym zakresie konsultacje publiczne (KRRiT, 2019). Pierwsza ich część dotyczyła linearnych i nielinearnych audiowizualnych usług medialnych, obejmując następujące kwestie problemowe: 1) integralność audycji i audiowizualnych usług medialnych w kontekście definicji: programów i rozprowadzania, zwłaszcza w odniesieniu do możliwości wprowadzenia przez dostawców video-on-demand i platform udostępniania wideo (VSP) skrótów, zmian, przerw czy plansz nakładanych na treści wideo w celach handlowych za zgodą dostawców, którzy pierwotnie dostarczyli audiowizualne usługi medialne; 2) zakres i sposób umieszczania informacji na temat struktury właścicielskiej nadawców programów i dostawców video-on-demand; 3) finansowanie produkcji europejskiej w zależności od rodzaju audiowizualnej usługi medialnej; 4) rola organów państwa, zwłaszcza ministrów, Krajowej Rady Radiofonii i Telewizji oraz interesariuszy w systemie edukacji medialnej; 5) znaczenie samoregulacji, współregulacji i kodeksów dobrych praktyk z punktu widzenia ich spójności ze stosowanymi instrumentami prawnymi; 6) zmiana kryterium ograniczeń czasowych handlowych przekazów audiowizualnych, sposoby lokowania produktu; 7) ochrona konsumenta, w szczególności praw osób niepełnosprawnych, przepisy przeciwdziałające reklamie niezdrowej żywności w usługach video-on-demand. Podniesiono też kwestię zmiany podejścia regulacyjnego w kierunku systemu czterostopniowego: 1) koncesje dla nadawców naziemnych; 2) ich uproszczone wersje dla nadawców satelitarnych, kablowych i rozpowszechniających program w systemach teleinformatycznych; 3 ) rejestr dla dostawców usług nielinearnych i operatorów rozprowadzających program oraz 4) działalność prowadzona na zasadach ogólnych, niereglamentowana, dla platform udostępniania wideo, z zastrzeżeniem obowiązku zgłoszenia usługi do elektronicznego wykazu. Druga część odnosiła się szczegółowo do usług platform udostępniania wideo. Zawierała przede wszystkim pytania w zakresie: 1) jurysdykcji i organizacji elektronicznego ich wykazu, w tym kryteriów ich wyznaczania; 2) obowiązywania przepisów, dotyczących handlowych przekazów audiowizualnych, ich wskazywania i oznaczania, wyboru środków, umożliwiających wypełnienie wymogów; 3) sposobów ochrony ogółu użytkowników, a w szczególności osób małoletnich, w zakresie stosowania instrumentów prawnych, proceduralnych, sankcji, samoregulacyjnych, pozasądowego rozstrzygania sporów, edukacji.

Wielość zagadnień i ich złożoność uwidacznia zakres wątpliwości regulacyjnych i interpretacyjnych dotyczących wprowadzanych zmian, w szczególności tych, 
które dotyczą usług platform udostępniania wideo ${ }^{17}$. Wskazują na to też odpowiedzi udzielone przez interesariuszy oraz raporty składane przez państwa członkowskie (KRRiT, 2019) ${ }^{18}$. Na obecnym etapie trudno nawet o ich wyczerpującą egzemplifikację. Nasuwa się jednak pewna podstawowa uwaga związana $\mathrm{z}$ definiowaniem występujących w dyrektywie 2018/1808/UE pojęć, zwłaszcza związanych z nowo wprowadzonymi w jej ramy usługami platform udostępniania wideo. Jak się wydaje, definiowanie powinno być dokonywane w oparciu o transparentne wytyczne. Przykładem jest tu fakultatywna inicjatywa Komisji Europejskiej sporządzenia takich wytycznych w odniesieniu do kryterium zasadniczego „celu czy funkcji” medialnej niniejszych platform i ukierunkowania właśnie na praktyczne i spójne, w rozumieniu wspólnotowym, wdrażanie tego wymogu. Wskazuje się na potrzebę badania związków: 1) między zawartością audiowizualną a główną działalnością gospodarczą; 2) ilościowym i jakościowym znaczeniem treści o tym charakterze w serwisie; 3) generowaniem przez nie przychodów lub stosowaniem narzędzi je pozycjonujących. Sprawa jest trudna do jednoznacznego przesądzenia, istnieją bowiem portale społecznościowe i strony internetowe ze znacznym udziałem materiałów wideo, które nie są jednak ukierunkowane na ich udostępnianie, ergo niechętne do poddania się ściślejszym rygorom prawnym, związanym w szczególności z obowiązkami, implikowanymi wymogami względem handlowych przekazów audiowizualnych, a dotyczącymi np. przedmiotowych zakazów lub ograniczeń reklamowych (na przykład odnośnie ukrytej jej formy w Internecie). Z jednej strony prawodawca unijny dąży do objęcia zakresem DAUM jak największej liczby usług i podmiotów je świadczących, podkreślając znaczenie serwisów społecznościowych jako medium wymiany informacji, nośnik rozrywki i edukacji, konkurujące na tym samym rynku i o tych samych odbiorców co audiowizualne usługi medialne, $\mathrm{z}$ drugiej strony natomiast ex lege z zakresu dyrektywy wyłączono oparte na różnych kryteriach: 1) krótkie formy wideo wbudowane w materiał redakcyjny elektronicznych wersji gazet i czasopism, animowane obrazy (tj. gify); 2) przejawy działalności niedochodowej, w tym prywatnej ${ }^{19}$.

17 „It is questionable whether the requirements set out in the AVMS Directive are indeed a significant burden, especially as, for the most part, video sharing platform providers already apply adequate measures as set out in the AVMS Directive. Undoubtedly, the most important change will be that, from now on, the video sharing platform provider will be subject to the media regulator and will have to be registered. Moreover, the video sharing platform provider will be subject to the AVMS Directive even if it is located outside the EU, if another entity from the provider's corporate group is located within the EU', https://www.jdsupra.com/legalnews/changes-to-the-audiovisualmedia-74103/ (dostęp: 12.04.2020).

18 Por. np.: http://eulawanalysis.blogspot.com/2018/05/revision-of-audiovisual-media-services. html.

19 Podobnie wobec innych omawianych tu zagadnień, na przykład kwot europejskich. 


\section{Podsumowanie i wnioski}

Podsumowując wstępne uwagi co do zmian zawartych w dyrektywie 2018/1808, należy zauważyć, że oceny ich efektywności - zwłaszcza w kontekście podniesienia konkurencyjności europejskiego sektora mediów audiowizualnych - dokonuje się na poziomie ustawodawczym - transponującym standardy do wewnętrznych porządków prawnych krajów członkowskich. Po ich wprowadzeniu zasadne jest komparatystyczne zbadanie różnic implementacyjnych, ukierunkowane na: ich zidentyfikowanie i wyeliminowanie problemów interpretacyjnych, stojących w opozycji do celu nowelizacji; jak wskazano wyżej, ważną rolę odgrywać tu może Komisja Europejska. Płaszczyzna stosowania niniejszych postanowień przez krajowe organy administracyjne i szeroko rozumiany wymiar sprawiedliwości ma charakter następczy, ergo najważniejsze znaczenie ma transparentność i precyzyjność procesu ich wdrażania.

Analizując obecny etap rozwoju mediów audiowizualnych, w ramach którego ich częścią stają się przynależne do tej pory do tak zwanej wolnej strefy Internetu usługi platform udostępniania wideo, można przypuszczać, że kontrowersje, wynikające dotychczas z dychotomii: mediów, zobowiązanych do zrównoważenia interesu publicznego i wartości kulturowych z wymogami konkurencyjnej gry rynkowej, poszerzą się o kwestię potrzeby lub konieczności włączenia kolejnych z nich w rygorystyczny reżim regulacyjny, ergo w dylemat wyboru między Scyllą a Charybdą.

\section{Bibliografia}

Badźmirowska-Masłowska K. (2008). Working Document on the Transition to Digital Broadcasting. „IRIS”, No. 2.

Badźmirowska-Masłowska K. (2013). Rozwój nowych technologii komunikacyjnych a bezpieczeństwo dzieci w Unii Europejskiej (1996-2011). Perspektywa prawna. W: A. Andrzejewska, J. Bednarek, S. Ćmiel (red.), Człowiek w świecie rzeczywistym i wirtualnym. Nowy wymiar zagrożeń w świecie realnym i wirtualnym, t. 1 (s. 213-260). Józefów: Wydawnictwo Wyższej Szkoły Gospodarki Euroregionalnej im. Alcide De Gasperi.

Badźmirowska-Masłowska K. (2017). Protecting Minors from Internet Threats: Legal Instruments or Alternative Measures? W: M. Sitek, A.F. Uricchio, I. Florek (eds.), Human Rights: Between Needs and Possibilities (s. 35-58). Józefów: Alcide De Gasperi University of Euroregional Economy.

Badźmirowska-Masłowska K., Jędras H. (2001). Polska w WTO - Zobowiązania Polski wynikające z członkostwa w Światowej Organizacji Handlu istotne dla sektora audiowizualnego. „Biuletyn KRRiT”, nr 4, s. 4.

Cabrera Blázquez F.J., Cappello M., Grece C., Valais S. (2016). VOD, Platforms and OTT: Which Promotion Obligations for European Works? „IRIS Plus”, No. 3, s. 37-39.

Castells M. (2014). Nowe indywidualne mass media. Tłum. A. Dwulit. Pobrane z: http://www. monde-diplomatique.pl/LMD7/index.php?id=3 (dostęp: 20.04.2014).

Chałubińska-Jentkiewicz K. (2011). Media audiowizualne. Konflikt regulacyjny w dobie cyfryzacji. Warszawa: Wolters Kluwer Polska. 
Cole M.D. (2018). The AVMSD Jurisdiction Criteria Concerning Audiovisual Media Service Providers after the 2018 Reform. Sarsbrucken: EMR.

Dobek-Ostrowska B. (red.). (2007). Media masowe na świecie. Modele systemów medialnych i ich dynamika rozwojowa. Wrocław: Wydawnictwo Uniwersytetu Wrocławskiego.

Hallin D.C., Mancini P. (2007). Systemy medialne. Trzy modele mediów i polityki w ujęciu porównawczym. Kraków: Wydawnictwo Uniwersytetu Jagiellońskiego.

Jenkins H. (2001). Convergence? I Diverge. „Technology Review”, $1^{\text {st }}$ June. Pobrane z: http:// web.mit.edu/21fms/People/henry3/converge.pdf (dostęp: 10.04.2020).

Jenkins H. (2006). Convergence Culture: Where Old and New Media Collide. New York-London: New York University Press.

Jakubowicz K. (2010). Unia Europejska a media. Między kultura a gospodarka. Warszawa: Wydawnictwa Akademickie i Profesjonalne.

Kasperkiewicz W. (2004). The concept of an information society in the European Union. "Acta Universitatis Lodziensis. Folia Oeconomica", nr 182, s. 309-318.

Klafkowska-Waśniowska K. (2016). Swobodny przepływ audiowizualnych usług medialnych na żądanie w Unii Europejskiej. Warszawa: Wolters Kluwer Polska.

Kowalski T. (2014). Ekonomiczne badania nad mediami jako element nauki o mediach. „Studia Medioznawcze", nr 2(57), s. 15-36.

Krzysztofek K. (2006). Status mediów cyfrowych: stare i nowe paradygmaty. „Global Media Journal - Polish Edition", No. 1.

Lange A., with the collaboration of Benhamou N., Joux A., Gros H., Le Guen J.M. (2009). Video on Demand and Catch-up TV in Europe. Strasbourg: European Audiovisual Observatory. Pobrane z: http://www.obs.coe.int/documents/205595/264625/VOD+2009+EN. pdf/78bbecb7-7c8f-4b67-8771-1189872a9637 (dostęp: 12.06.2016).

Mik C. (1999). Media masowe w europejskim prawie wspólnotowym. Toruń: TNOiK.

Nierenberg B., (2013). Zarządzania mediami - koncepcje i metody badawcze. „Współczesne Zarządzanie", Vol. 11(4), s. 41-47.

Nikoltchev S., European Audiovisual Observatory (eds.). (2006). Broadcasters' Obligations to Invest in Cinematographic Production. „IRIS Special”, No. 2016.

Nowak C. (2014). Wpływ procesów globalizacyjnych na polskie prawo karne. Warszawa: Wolters Kluwer Polska.

Romanowski M. (1999). Francuski model regulacji mediów audiowizualnych. „Przegląd Sejmowy", nr 4(33), s. 35-55.

Rossini M. (2005-2007). European Court of Justice: Case Mediakabel BV / Commissariaat voor de Media. „IRIS”, No. 4/3.

Tofler A. (2002). Odmasowione środki przekazu. W: M. Hopfinger (red.), Nowe media w komunikacji społecznej w XX wieku (s. 441-447). Warszawa: Oficyna Naukowa.

Van Eijk N. (2011). Net Neutrality and Audiovisual Services. W: S. Nikoltchev (ed.), Why Discuss Network Neutrality? „IRIS Plus”, No. 5, s. 7-19.

\section{Akty prawne:}

C/2018/1177. Commission recommendation (EU) 2018/334 of 1 March 2018 on measures to effectively tackle illegal content online.

$\operatorname{COM}(2015) 192$ final. Communication from the Commission to the European Parliament, the Council, the European Economic and Social Committee and the Committee of the Regions, A Digital Single Market Strategy for Europe. SWD(2015) 100 final. Brussels, 6.05.2015. 
$\operatorname{COM}(2016) 587$ final. Communication from the Commission to the European Parliament, the Council, the European Economic and Social Committee and the Committee of the Regions, Connectivity for a Competitive Digital Single Market - Towards a European Gigabit Society. SWD(2016) 300 final. Brussels, 14.09.2016.

$\operatorname{COM}(84) 300$ final. Green Paper on the establishment of a common market in broadcasting especially broadcasting by satellite and cable. Brussels, $14^{\text {th }}$ June 1984 . Pobrane $z$ : https:// ec.europa.eu/digital-single-market/en/news/1984-\%E2\%80\%93-green-paper-establishment-common-market-broadcasting-especially-satellite-and-cable (dostęp: 12.04.2020).

COM/2013/0231 final. Green Paper Preparing for a Fully Converged Audiovisual World: Growth, Creation and Values.

Dz.U. $1995 \mathrm{Nr}$ 32, poz. 160. Europejska konwencja o telewizji ponadgranicznej, sporządzona w Strasburgu dnia 5 maja $1989 \mathrm{r}$.

Dz.U. 2004 r., Nr 28, poz. 250. Protokół poprawek sporządzony w Strasburgu dnia 9 września 1998 r. do Europejskiej konwencji o telewizji ponadgranicznej, sporządzonej w Strasburgu dnia 5 maja $1989 \mathrm{r}$.

Dz.Urz. UE C 257/01. Komunikat Komisji w sprawie stosowania zasad pomocy państwa wobec radiofonii i telewizji publicznej.

Dz.Urz. UE C 326/312. Protokół (nr 29) w sprawie systemu publicznego nadawania w Państwach Członkowskich.

Dz.Urz. UE L 202/60. Dyrektywa 97/36/WE Parlamentu Europejskiego i Rady z dnia 30 czerwca 1997 r. zmieniająca dyrektywę Rady 89/552/EWG, w sprawie koordynacji niektórych przepisów ustawowych, wykonawczych i administracyjnych Państw Członkowskich dotyczących wykonywania telewizyjnej działalności transmisyjnej.

Dz.Urz. UE L 298/23. Dyrektywa 89/552/EWG Parlamentu Europejskiego i Rady z dnia 3 października 1989 r. w sprawie koordynacji niektórych przepisów ustawowych, wykonawczych i administracyjnych państw członkowskich dotyczących świadczenia audiowizualnych usług medialnych (dyrektywa o audiowizualnych usługach medialnych).

Dz.Urz. UE L 303/69. Dyrektywa Parlamentu Europejskiego i Rady (UE) 2018/1808 z dnia 14 listopada 2018 r. zmieniająca dyrektywę 2010/13/UE w sprawie koordynacji niektórych przepisów ustawowych, wykonawczych i administracyjnych państw członkowskich dotyczących świadczenia audiowizualnych usług medialnych (dyrektywa o audiowizualnych usługach medialnych) ze względu na zmianę sytuacji na rynku.

Dz.Urz. UE L 95/1. Dyrektywa Parlamentu Europejskiego i Rady 2010/13/UE z dnia 10 marca 2010 r. w sprawie koordynacji niektórych przepisów ustawowych, wykonawczych i administracyjnych państw członkowskich dotyczących świadczenia audiowizualnych usług medialnych (dyrektywa o audiowizualnych usługach medialnych) (wersja ujednolicona).

Traktaty: https://europa.eu/european-union/law/treaties_en (11.04.2020).

\section{Inne źródła:}

Apa E., Gangemi G. (2020). The New Audiovisual Media Services Directive and the Promotion of European Works by On-Demand Media Service Providers. Pobrane z: www.medialaws.eu/ wp-content/uploads/2019/03/2-2019-Apa-Gangemi.pdf (dostęp: 12.04.2020).

Badźmirowska-Masłowska K. (2002). Materiał na posiedzenie sejmowych Komisji Kultury i Środków Przekazu oraz Komisji Kultury Fizycznej i Sportu pt. „Transmisje z Mistrzostw Świata 2002 roku w piłce nożnej”. „Biuletyn KRRiT”, nr 1, s. 10 i n.

European Commission (2015). ERGA report on material jurisdiction in a converged environment. Raport z 18 grudnia. Pobrane z: https://ec.europa.eu/digital-single-market/en/ news/erga-report-material-jurisdiction-converged-environment (dostęp: 12.04.2020). 
European Commission (2018a). Audiovisual Media Services Directive. Pobrane z: https:// ec.europa.eu/digital-single-market/en/audiovisual-media-services-directive-avmsd (dostęp: 12.04.2020).

European Commission (2018b). Pobrane z: Protection of film heritage, https://ec.europa.eu/ digital-single-market/en/film-heritage (dostęp: 12.04.2020).

https://ec.europa.eu/culture/our-programmes-and-actions/doc411_en (dostęp: 12.04.2020).

https://ec.europa.eu/programmes/creative-europe/node_en; https://kreatywna-europa.eu/ (dostęp: 12.04.2020).

Kreatywna Europa (2014-2020). Program Media. Pobrane z: https://kreatywna-europa.eu/ od-1991-roku-program-media-inwestuje-w-europejski-sektor-audiowizualny/ (dostęp: 12.04.2020).

KRRiT (2018). Wideo w sieci - Modele dystrybucji i monetyzacji plików wideo w języku polskim w sieci Internet. Raport KRRiT. Pobrane z: http://www.krrit.gov.pl/krrit/aktualnosci/ news,2619,raport-krrit-wideo-w-sieci---modele-dystrybucji-i-monetyzacji-plikow-wideo-w-jezyku-polskim-w-sieci.html (dostęp: 12.04.2020).

KRRiT (2019). Publiczne konsultacje w sprawie nowelizacji dyrektywy o audiowizualnych ustugach medialnych. Pobrane z: http://www.krrit.gov.pl/regulacje-prawne/konsultacje-krrit/ news, 2873,krrit-oglasza-publiczne-konsultacje-w-sprawie-nowelizacji-dyrektywy-o-audiowizualnych-uslugach.html (dostęp: 12.04.2020).

Mediakabel BV vs Commissariaat voor de Media (C-89/04), rozpatrywana w trybie prejudycjalnym, przez Trybunał Sprawiedliwości (TS). Wyrok Trybunału (trzecia izba) z dnia 2 czerwca $2005 \mathrm{r}$. 